Netjes, J., Rijken, M. Ontwikkeling van lichamelijke beperking in het verleden mede bepalend voor huidige participatie op de arbeidsmarkt. Tijdschrift voor Bedrijfs- en

\begin{tabular}{|l|l|}
\hline $\begin{array}{l}\text { Postprint } \\
\text { Version }\end{array}$ & 1.0 \\
\hline Journal website & http://vb23.bsl.nl/frontend/default.asp?product id=0929-600X \\
\hline Pubmed link & \\
\hline DOI &
\end{tabular}

This is a NIVEL certified Post Print, more info at http://www.nivel.eu

\title{
Ontwikkeling van lichamelijke beperking in het verleden mede bepalend voor huidige participatie op de arbeidsmarkt
}

\author{
JUSTINE NETJES, MIEKE RIJKEN
}

Drs. J. Netjes en dr. P.M. Rijken zijn als onderzoekers werkzaam bij het Nederlands instituut voor onderzoek van de gezondheidszorg (NIVEL).

CORRESPONDENTIEADRES E-mail: justine.netjes@gmail.com.

\begin{abstract}
SAMENVATTING
Gezien de toekomstige krapte op de arbeidsmarkt als gevolg van vergrijzing is het belangrijk dat zo veel mogelijk mensen in Nederland aan het werk gaan en er zo min mogelijk uitval uit het arbeidsproces plaatsvindt.

Mensen met lichamelijke beperkingen participeren als groep minder vaak op de arbeidsmarkt. Eerder onderzoek laat zien dat arbeidsparticipatie onder mensen in deze groep sterk verschilt. Dit hangt samen met de aard en de ernst van de beperkingen. Wij onderzochten of ook het moment waarop de beperking in iemands leven is ontstaan en het verloop ervan sindsdien van invloed is op het verrichten van werk.

Hiervoor hebben wij een vragenlijst voorgelegd aan een landelijke steekproef van mensen met een lichamelijke beperking (respons 87\%, n=992 mensen van $15 \mathrm{t} / \mathrm{m} 64$ jaar) waarin zij retrospectief vragen beantwoordden over het ontstaan en de ontwikkeling van hun beperking in het verleden. De resultaten laten zien dat ongeacht de aard en ernst van de huidige beperkingen, mensen met een beperking die over de jaren heen verergerde een kleinere kans hebben op arbeidsdeelname. Het moment van ontstaan van de beperking bleek geen effect te hebben op de huidige arbeidsdeelname.
\end{abstract}

Het hebben van betaald werk is voor mensen met beperkingen net zo belangrijk als voor andere mensen. Het geeft, behalve economisch voordeel, veel mensen het gevoel een nuttige bijdrage te leveren aan de samenleving en het kan het gevoel van eigenwaarde en de individuele identiteit versterken. ${ }^{1}$

Desondanks participeren mensen met beperkingen minder vaak op de Nederlandse arbeidsmarkt dan andere burgers. Van de groep mensen met lichamelijke beperkingen verrichtte in 2010 ruim een derde (38\%) betaald werk voor ten minste 12 uur per week,* tegenover twee derde van de totale Nederlandse bevolking in de 
Netjes, J., Rijken, M. Ontwikkeling van lichamelijke beperking in het verleden mede bepalend voor huidige participatie op de arbeidsmarkt. Tijdschrift voor Bedrijfs- en

Verzekeringsgeneeskunde: 2012, 20(6), 248-254

leeftijd van 15 t/m 64 jaar. ${ }^{2,3}$ Gezien de toekomstige krapte op de arbeidsmarkt als nivel gevolg van de vergrijzing, is het ook voor de Nederlandse samenleving belangrijk dat mensen met beperkingen 'meedoen naar vermogen'.

Hoewel de arbeidsparticipatiegraad onder mensen met lichamelijke beperkingen over het geheel genomen laag is, zijn er wel verschillen binnen deze groep: ouderen, vrouwen en laag opgeleide mensen nemen minder vaak deel aan het arbeidsproces. Specifiek voor mensen met beperkingen geldt dat ook de aard en ernst van hun beperkingen een rol spelen bij het wel of niet (kunnen) werken. Onder mensen met een lichamelijke chronische ziekte of beperking is de kans dat zij werken kleiner, wanneer zij motorische beperkingen en/of ernstige beperkingen ervaren. ${ }^{4,5}$ In veel onderzoek wordt een relatie gelegd tussen het huidige niveau van de beperkingen en de huidige deelname aan de arbeidsmarkt. ${ }^{2-5}$ Maar het gegeven dat men op dit moment wel of niet betaald werk verricht, is in feite het resultaat van een gebeurtenis uit het verleden. Indien men bijvoorbeeld al op kinderleeftijd een beperking had, kan dit de school-/studiecarrière en de toetreding tot de arbeidsmarkt hebben bemoeilijkt. Een progressieve ziekte op volwassen leeftijd kan ertoe leiden dat men uiteindelijk de beslissing moet nemen om met werken te stoppen. Met andere woorden, het moment in het verleden waarop de beperkingen zijn ontstaan en hoe ze sindsdien zijn verlopen kunnen hun weerslag hebben op de huidige arbeidssituatie. Daarom is het belangrijk om bij het verklaren van een verschil in deelname aan het arbeidsproces tussen mensen met beperkingen niet alleen de aard en ernst van de huidige beperkingen in beschouwing te nemen, maar ook het moment van ontstaan van de beperkingen en het verloop ervan sindsdien.

Dit onderzoek heeft een tweeledig doel:

1. inzicht geven in het ontstaan en verloop van beperkingen binnen een landelijk representatieve groep van mensen met lichamelijke beperkingen; en

2. nagaan of de periode in het leven waarin de beperkingen zijn ontstaan en het verloop ervan sindsdien, bijdragen aan het verklaren van verschillen in arbeidsparticipatie tussen mensen met lichamelijke beperkingen.

Uitgaande van de genoemde doelen, hebben we de volgende onderzoeksvragen geformuleerd:

1. Hoe kunnen de huidige beperkingen van mensen met lichamelijke beperkingen worden beschreven naar (a) hun aard en (b) hun ernst?

2. Hoe kan het verleden van de lichamelijke beperkingen worden beschreven naar (a) het moment van ontstaan, (b) de oorzaken van ontstaan en (c) het verloop ervan sindsdien?

3. In welke mate voorspellen het moment van het ontstaan en het verloop van de beperkingen de arbeidsparticipatie van mensen met lichamelijke beperkingen (naast hun sociaaldemografische kenmerken en de aard en ernst van hun huidige beperkingen)?

\section{METHODE}

\section{Nationaal Panel Chronisch zieken en Gehandicapten}

Om de onderzoeksvragen te beantwoorden, hebben wij gebruik gemaakt van gegevens die in 2009 zijn verzameld onder de deelnemers van het Nationaal Panel Chronisch zieken en Gehandicapten (NPCG). Dit is een landelijk representatief panel bestaande uit circa 4000 mensen met lichamelijke chronische ziekten en/of matige of ernstige lichamelijke beperkingen. ${ }^{6}$ De deelnemers aan het NPCG worden geworven 
Netjes, J., Rijken, M. Ontwikkeling van lichamelijke beperking in het verleden mede bepalend voor huidige participatie op de arbeidsmarkt. Tijdschrift voor Bedrijfs- en

Verzekeringsgeneeskunde: 2012, 20(6), 248-254

via huisartsenpraktijken (landelijke steekproef uit de Registratie Gevestigde Huisartsen) op basis van een door een arts gestelde diagnose van een chronische somatische ziekte. Mensen met lichamelijke beperkingen stromen daarnaast in vanuit periodieke landelijke bevolkingsonderzoeken zoals het Aanvullend Voorzieningengebruik Onderzoek (SCP) ${ }^{7}$ en het Periodiek Leefsituatie Onderzoek $(\mathrm{CBS})^{8}$ op basis van hun antwoorden op screeningsvragen over de aanwezigheid en ernst van lichamelijke beperkingen. De panelleden doen twee keer per jaar (voor- en najaar) mee aan een reguliere enquête. Door middel van de najaarsenquête wordt jaarlijks informatie verkregen over het verrichten van betaald werk door de respondenten.

Ten behoeve van dit specifieke onderzoek hebben de panelleden in de najaarsenquête van 2009 eenmalig aanvullend retrospectief vragen beantwoord over het ontstaan en het beloop van hun (eventuele) lichamelijke beperkingen in het verleden. Deze vragen zijn door onszelf geformuleerd.

De gecombineerde gegevens uit deze enquête van 2009 zijn gebruikt voor dit onderzoek.

\section{Data}

Sociaaldemografische gegevens. In dit onderzoek zijn de volgende sociaal demografische gegevens gebruikt: geslacht, leeftijd (in 2011) en opleidingsniveau. Opleidingsniveau betrof het hoogst behaalde opleidingsniveau en werd uitgesplitst in drie categorieën: laag opleidingsniveau ( $\mathrm{t} / \mathrm{m} \mathrm{lbo}$ ), middelbaar ( $\mathrm{t} / \mathrm{m} \mathrm{mbo}$ ) en hoog opleidingsniveau (hbo en wo).

Kenmerken van de beperking. De aard en ernst van de lichamelijke beperking(en) zijn met de volgende vragen nagevraagd, waarin de keuzemogelijkheden bestonden uit: nee, gering, flink of zeer ernstig: heeft u problemen met zien (ook als $u$ een bril of contactlenzen draagt); heeft u problemen met horen (ook nog als u een gehoortoestel draagt); heeft u problemen met het gebruiken van uw vingers, handen of armen; heeft u problemen met staan of lopen? Wanneer de beperking is ontstaan werd vastgesteld door de vraag: wanneer zijn deze problemen ontstaan? De antwoordcategorieën waren: bij geboorte, in de jeugd (t/m 18 jaar), op jongvolwassen leeftijd (19 t/m 39 jaar), op middelbare leeftijd (40 t/m 64 jaar), op oudere leeftijd (vanaf 65 jaar). Deze vraag is per beperking gesteld.

Het verloop van de beperkingen werd gemeten door de vraag: hoe zijn de problemen verlopen? Met als keuzemogelijkheden: stabiel gebleven, langzaam verergerd, snel verergerd, soms erger/ soms minder erg, nu minder ernstig.

De oorzaak/oorzaken van de beperking volgens de respondent is/zijn gemeten door per beperking de vraag te stellen: waardoor zijn de problemen ontstaan? Met als keuzemogelijkheden: vanwege chronische ziekte, veroudering, aangeboren stoornis, ziekte/problemen tijdens de zwangerschap, ongeval, ziekte van voorbijgaande aard, erfelijke factoren, anders en weet niet.

Arbeidssituatie. De huidige arbeidssituatie is nagegaan door middel van de vraag: verricht u momenteel betaald werk? Zo ja, hoeveel uur? Mensen die ten minste 12 uur per week betaald werk verrichten, worden beschouwd als participerend op de arbeidsmarkt (dit is conform de definitie van het CBS). ${ }^{9}$

\section{Steekproef}

Voor dit onderzoek zijn alleen gegevens gebruikt van respondenten die aangaven ten minste geringe problemen te hebben op het gebied van zien, horen, gebruik van 
Netjes, J., Rijken, M. Ontwikkeling van lichamelijke beperking in het verleden mede bepalend voor huidige participatie op de arbeidsmarkt. Tijdschrift voor Bedrijfs- en

Verzekeringsgeneeskunde: 2012, 20(6), 248-254

vingers, handen of armen en/of staan of lopen. De respondentengroep werd bovendien afgebakend tot mensen in de leeftijd van $15 \mathrm{t} / \mathrm{m} 64$ jaar. Dit resulteerde in 992 respondenten: 35\% mannen en 65\% vrouwen. De gemiddelde leeftijd was 54 jaar. Een derde van de respondenten heeft een laag opleidingsniveau en $22 \%$ een hoog opleidingsniveau. Indien respondenten meerdere beperkingen rapporteerden, is bij de analyse het ontstaan en beloop van de eerst ontstane beperking gebruikt. Niet alle respondenten hebben alle vragen ingevuld. Indien er geen antwoord bekend is van een respondent, wordt dit gerapporteerd als ontbrekende waarde, die dan in de betreffende analyse niet is meegenomen.

Voor alle figuren geldt $n=974$ met uitzondering van figuur $3(n=970)$. Voor de tabel geldt $n=913$.

\section{Statistische analyses}

De analyses zijn uitgevoerd met het programma STATA 10.0. Ter beantwoording van de onderzoeksvragen 1 en 2 zijn univariate en bivariate analyses uitgevoerd: berekening van gemiddelden en percentages, kruistabellen, chikwadraattoetsen en variantieanalyse. De derde onderzoeksvraag is onderzocht door middel van een logistische regressieanalyse, waarbij het al of niet hebben van betaald werk als de afhankelijke variabele werd genomen. In drie stappen zijn onafhankelijke variabelen aan het model toegevoegd: allereerst de variabelen over het moment van ontstaan en het verloop van de beperking sindsdien (model 1), vervolgens de aard en ernst van de huidige beperkingen (model 2) en ten slotte de variabelen geslacht, leeftijd en opleidingsniveau (model 3). Door toevoeging van variabelen in het tweede en derde model, werd gecorrigeerd voor eventuele andere verschillen tussen mensen met beperkingen die mogelijk samenhangen met hun arbeidssituatie, zoals de hiervoor beschreven verschillen in leeftijd. In de tabel worden alleen de significante effecten weergegeven $(p<0,05)$; niet significante effecten worden weergegeven met -.

\section{RESULTATEN}

\section{Aard en ernst van de huidige beperking}

Van de totale groep respondenten rapporteerde bijna driekwart (72\%) problemen te hebben met staan of lopen. Ruim de helft (55\%) heeft (daarnaast) problemen met het gebruiken van vingers, handen of armen. Veertig procent heeft problemen met zien en 23\% gaf aan problemen te hebben met horen. Veel mensen hebben meerdere beperkingen (61\%), waarvan de meest genoemde combinatie die van problemen met het gebruiken van handen, vingers of armen en problemen met staan of lopen zijn.

\section{[TABLE 1]}

Wanneer we kijken naar de ernst van de beperking geven de meeste mensen (58\%) aan geringe last van hun beperking(en) te hebben. Dit zijn dus mensen die weliswaar lichamelijke beperkingen hebben, maar hier weinig hinder van ondervinden. Een derde heeft een matig ernstige beperking en bijna één op de tien heeft een ernstige beperking. Onze steekproef bevat in vergelijking met eerder landelijk onderzoek ${ }^{10}$ minder mensen met lichte beperkingen (58\% versus 68\%), en meer mensen met een matige beperking (33\% versus 24\%). Dit komt door de manier waarop het NPCG is samengesteld: voor de inclusie geldt een medisch gediagnosticeerde chronische 
Netjes, J., Rijken, M. Ontwikkeling van lichamelijke beperking in het verleden mede bepalend voor huidige participatie op de arbeidsmarkt. Tijdschrift voor Bedrijfs- en

Verzekeringsgeneeskunde: 2012, 20(6), 248-254

ziekte of matige of ernstige lichamelijke beperkingen (zoals vastgesteld op basis van de SCP-vragenlijst voor lichamelijke beperkingen). ${ }^{7}$

\section{Moment van ontstaan, het verloop en oorzaak van de beperking}

Bij het merendeel van de respondenten is de eerste beperking na het $40^{\text {ste }}$ jaar ontstaan (figuur 1).

Bij een kleinere groep is de beperking ontstaan op jongvolwassen leeftijd en bij een op de vijf was de beperking al bij geboorte aanwezig of tijdens de jeugd ontstaan. Voor de grootste groep is de beperking in de loop der tijd verergerd (figuur 2). Een kleine groep (6\%) meldt dat hun beperking in de loop der tijd verbeterd is.

\section{[FIGUUR 1, FIGUUR 2, FIGUUR 3]}

Het hebben van een chronische ziekte werd door veel respondenten als belangrijkste oorzaak van hun beperkingen genoemd (31\%). Ook het ouder worden werd door een flink deel van de respondenten (16\%) als belangrijkste oorzaak genoemd, maar een even groot deel gaf aan niet te weten waardoor hun beperkingen zijn ontstaan (figuur $3)$.

\section{[FIGUUR 4]}

\section{Huidige arbeidssituatie}

Ruim een derde (37\%) van de respondenten had op het moment van afname van de enquête een betaalde baan voor ten minste 12 uur per week. Bijna vier op de vijf werkenden rapporteerden een vast dienstverband te hebben. De meesten werkten 20 tot 34 uur per week of 35 uur per week of meer (respectievelijk 43\% en 42\%). De grootste groep was werkzaam in dienstverlenende functies, administratieve functies of ambachts-/industrie- of transportgerelateerde beroepen.

Van de mensen die niet participeerden op de arbeidsmarkt had bijna 90\% in het verleden wel een betaalde baan. Bij de meeste mensen (59\%) was de beperking de belangrijkste reden geweest om te stoppen met werken. Voor 15\% was de beperking een van de redenen geweest om te stoppen en voor een kwart van de mensen speelde de beperking geen rol bij het stoppen met werken.

\section{[FIGUUR 5]}

Verschil in arbeidsparticipatiegraad naar moment van ontstaan van beperking In figuur 4 is te zien dat onder mensen met lichamelijke beperkingen de arbeidsparticipatiegraad het hoogst is in de groepen die voor hun $40^{\text {ste }}$ jaar beperkingen kregen (43\% en $41 \%$ ten opzichte van $33 \%$ ).

We merken hierbij op dat de groep die rapporteerde dat zij al in hun jeugd een beperking hadden en de groep die op jongvolwassen leeftijd een beperking kreeg, gemiddeld genomen jonger zijn dan de groep bij wie de beperking na hun $40^{\text {ste }}$ ontstond (gemiddelde leeftijd respectievelijk 49 en 50 jaar ten opzichte van 58 jaar, $p<0,001)$. Het is bekend dat de arbeidsparticipatiegraad fors daalt vanaf 55 jaar. ${ }^{11}$

\section{Verschil in arbeidsparticipatiegraad naar verloop van beperking}

Verschillen in arbeidsparticipatiegraad zien we ook naar het verloop van de beperking. Mensen bij wie de beperking in de loop der tijd is verergerd, participeren minder vaak op de arbeidsmarkt dan mensen bij wie de beperking niet is verergerd (figuur 5). 
Netjes, J., Rijken, M. Ontwikkeling van lichamelijke beperking in het verleden mede bepalend voor huidige participatie op de arbeidsmarkt. Tijdschrift voor Bedrijfs- en

Verzekeringsgeneeskunde: 2012, 20(6), 248-254

Echter, ook hier geldt dat de gemiddelde leeftijd niet in alle categorieën gelijk is. De mensen bij wie de beperking verergerde, zijn gemiddeld genomen ouder ( 55 jaar) dan de mensen die aangaven dat het verloop van hun beperking verbeterde (53 jaar), stabiel is gebleven (52 jaar) of een wisselend karakter had (51 jaar) $(p<0,001)$.

\section{Impact van moment van ontstaan en verloop beperking op arbeidsparticipatie}

Vervolgens hebben we onderzocht of het moment in iemands leven waarop een beperking is ontstaan en het verloop van de beperking sindsdien van voorspellende waarde zijn voor de arbeidsparticipatie van mensen met lichamelijke beperkingen op een later moment.

Moment van ontstaan. Mensen die reeds in hun jeugd een beperking hadden, hebben een grotere kans om betaald werk te verrichten dan mensen die na hun $40^{\text {ste }}$ een beperking kregen (tabel, model 1). Wanneer we corrigeren voor de aard en ernst van de huidige beperkingen (model 2), blijft dit effect bestaan. Tevens zien we dan dat ook degenen die op jongvolwassen leeftijd een beperking kregen een grotere kans hebben om deel te nemen aan het arbeidsproces dan de groep die na hun $40^{\text {ste }}$ beperkingen kreeg. Echter, als we in model 3 controleren voor sociaaldemografische kenmerken, heeft het moment van ontstaan van de beperkingen geen effect meer op het al of niet participeren op de arbeidsmarkt.

Verloop. De tabel laat tevens zien dat mensen bij wie de beperking in de loop der tijd verergerde, een kleinere kans hebben om deel te nemen aan het arbeidsproces dan degenen bij wie de beperking een ander verloop kende (model 1 en 2). In het derde model, waarin dus tevens gecontroleerd is voor sociaaldemografische verschillen, is dit effect nog steeds zichtbaar, zij het dat de regressiecoëfficiënten minder groot zijn en in het geval van een stabiel verloop (ten opzichte van een progressief verslechterend verloop) niet meer significant. Met andere woorden, ook wanneer rekening wordt gehouden met sociaaldemografische verschillen en verschillen in de aard en ernst van de huidige beperkingen, is de wijze waarop een beperking zich in het verleden heeft ontwikkeld, een significante voorspeller van arbeidsparticipatie onder mensen met lichamelijke beperkingen. Dit geldt alleen als de beperking in de loop der tijd verbeterde of verslechterde.

Als het verloop van de beperking door de jaren heen niet veranderde, heeft dat geen voorspellende waarde voor de huidige arbeidsparticipatie.

Andere factoren. De tabel laat ten slotte zien wat de aard van de beperkingen van voorspellende waarde is voor arbeidsparticipatie. Binnen de groep van mensen met lichamelijke beperkingen hebben de mensen met een gezichtsbeperking een grotere kans op arbeidsdeelname dan degenen met (nog) andere beperkingen. Problemen met staan of lopen hebben het meest negatieve effect op de kans op arbeidsdeelname van mensen met beperkingen. Duidelijk is ook dat naarmate mensen ernstigere beperkingen hebben de kans op arbeidsparticipatie afneemt. Deze resultaten zijn overeenkomstig de bevindingen uit eerdere studies. ${ }^{4,5}$ Uit onze analyse komen daarnaast de bekende sociaaldemografische effecten op arbeidsparticipatie naar voren. De kans op arbeidsparticipatie is kleiner voor vrouwen en ouderen (binnen de groep 15 t/m 64 jaar) en groter voor hoogopgeleide mensen.

\section{DISCUSSIE EN CONCLUSIE}

De gegevens die in dit onderzoek zijn gebruikt, zijn afkomstig van bijna 1000 mensen met lichamelijke beperkingen verspreid over heel Nederland. 
Netjes, J., Rijken, M. Ontwikkeling van lichamelijke beperking in het verleden mede bepalend voor huidige participatie op de arbeidsmarkt. Tijdschrift voor Bedrijfs- en

Verzekeringsgeneeskunde: 2012, 20(6), 248-254

De omvang van de groep en de landelijke spreiding ervan dragen ons inziens bij aan de validiteit van onze bevindingen. We merken hier echter nogmaals op dat onze steekproef relatief veel mensen met ernstiger beperkingen bevatte, dit als gevolg van de inclusiecriteria die voor het Nationaal Panel Chronisch zieken en Gehandicapten worden gehanteerd.

Een tweede kanttekening moet worden geplaatst bij het terugvragen naar het ontstaan van de beperking en het verloop ervan in het verleden.

Voor veel mensen betekende dit dat ze behoorlijk ver terug moesten gaan in de tijd, waardoor herinneringsbias een rol kan hebben gespeeld. We hebben dit geprobeerd zo veel mogelijk te ondervangen door niet precies te vragen naar het levensjaar waarin de (eerste) beperking was ontstaan, maar door dit te bevragen met grovere antwoordcategorieën (voor het $18^{\text {de }}$ jaar, na het $40^{\text {ste }}$ jaar, enz.). Hierdoor denken wij de kans op herinneringsbias aanzienlijk te hebben verkleind. Een nadeel hiervan is wel weer dat we geen heel genuanceerde conclusies kunnen trekken over de rol die het moment waarop een beperking in iemands leven is ontstaan, speelt bij arbeidsparticipatie. Gegeven deze kanttekeningen moet voorzichtigheid betracht worden bij het generaliseren van de resultaten. Desalniettemin geeft dit onderzoek meer inzicht in de arbeidssituatie van mensen met lichamelijke beperkingen en geeft het handreikingen voor verder onderzoek.

Als we kijken naar de aard en ernst van de beperkingen, kunnen we concluderen dat de grootste groep mensen problemen heeft met staan of lopen, en dat veel mensen last hebben van meerdere beperkingen. De grootste groep geeft aan geringe last te hebben van hun beperking(en).

Het moment van ontstaan van de beperking bleek geen effect te hebben op de huidige arbeidsdeelname.

Wel kunnen we concluderen dat de manier waarop beperkingen zich in het verleden hebben ontwikkeld mede bepalend is voor de huidige deelname aan de arbeidsmarkt van mensen met lichamelijke beperkingen. Mensen met een beperking die in de loop der tijd is verergerd, nemen minder vaak deel aan het arbeidsproces, ongeacht de aard en ernst van hun beperkingen op dit moment.

Omdat de ontwikkeling van een beperking doorwerkt op de arbeidssituatie op een later moment, is het belangrijk om mensen die lichamelijke beperkingen krijgen, al in een vroeg stadium te ondersteunen bij het behoud van werk, ook als de beperkingen op dat moment nog niet zo ernstig zijn. Voor bedrijfsartsen is het dus belangrijk dat ze proactief te werk gaan, dat wil zeggen zelf initiatieven nemen (of werkgevers daartoe aansporen) om werknemers met lichte beperkingen voorlichting en ondersteuning aan te bieden en niet te wachten totdat mensen met beperkingen concrete problemen ondervinden bij het verrichten van hun werk en dan vanwege ziekteverzuim bij hen terechtkomen.

NOOT

* Dit is conform de definitie die het CBS hanteert voor arbeidsparticipatie. 
Netjes, J., Rijken, M. Ontwikkeling van lichamelijke beperking in het verleden mede bepalend voor huidige participatie op de arbeidsmarkt. Tijdschrift voor Bedrijfs- en

Verzekeringsgeneeskunde: 2012, 20(6), 248-254

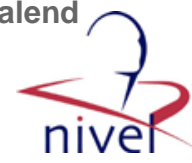

\section{LITERATUUR}

1. Waddell G, Burton AK. Is work good for your health and well-being? Norwich: TSO, 2006.

2. Meulenkamp T, Hoek $L$ van der, Cardol M. Deelname aan de samenleving van mensen met een beperking en ouderen. Participatiemonitor 2011. Utrecht: NIVEL, 2011.

3. CBS statline. Beroepsbevolking kerncijfers 2010; en Gezondheid, leefstijl, zorggebruik; t/m 2009.

4. Baanders AN, Rijken PM, Peters L. Labour participation of the chronically ill. A profile sketch. Eur J Public Health 2002; 12: 124-130.

5. Heijmans M, Veer J van der, Spreeuwenberg P, Rijken M. Kerngegevens Werk en inkomen. Rapportage 2011.

Monitor zorg- en leefsituatie van mensen met een chronische ziekte of beperking. Utrecht: NIVEL, 2011.

6. Calsbeek H, Spreeuwenberg P, Kerkhof MJW van, Rijken PM. Nationaal Panel Chronisch zieken en Gehandicapten. Kerngegevens Zorg 2005. Utrecht: NIVEL, 2006.

7. Klerk MMY de, Campen $C$ van, ledema J. SCP-beperkingenmaat voor lichamelijke beperkingen op basis van AVO 2003. Den Haag: Sociaal en Cultureel Planbureau, 2006 (SCP-werkdocument 121).

8. CBS. Permanent Onderzoek Leef Situatie (POLS).

9. CBS 2011: Artikel, 21-02-11 Arbeidsparticipatie naar leeftijd en geslacht: www.cbs.nl/nl$\mathrm{NL} /$ menu/themas/ arbeid-sociale-zekerheid/publicaties/arbeidsmarktvogelvlucht/ structuurarbeidsmarkt/2006-arbeids markt-vv-participatie-art.htm. Geraadpleegd 02-112011.

10. Klerk MMY de. Rapportage gehandicapten 2000.

Arbeidsmarktpositie en financiële situatie van mensen met beperkingen en/of chronische ziekten. Den Haag: Sociaal en Cultureel Planbureau, 2000.

11. CBS statline. Beroepsbevolking 2009; geslacht en leeftijd.

\section{TABELLEN EN FIGUREN}

\begin{tabular}{|c|c|c|c|}
\hline $\begin{array}{l}\text { Tabel } \\
\text { Effecten op arbeidsparticipatie }\end{array}$ & & & \\
\hline & Model $1^{\mathrm{b}}$ & Model $2^{c}$ & Model $3^{\mathrm{d}}$ \\
\hline Ontstaan en verloop van beperklng & & & \\
\hline Ontstaan voor 19de jaar (ref: op middelbare leeftijd) & 0,09 & 0,09 & - \\
\hline Ontstaan op jongvolwassen leeftijd (ref: op middelbare leeftijd) & - & 0,10 & - \\
\hline Verloop verbeterd (ref: verergerd) & 0,21 & 0,16 & 0,13 \\
\hline Verloop gelijk gebleven (ref: verergerd) & 0,18 & 0,09 & - \\
\hline Verloop fluctuerend (ref: verergerd) & 0,13 & 0,14 & 0,11 \\
\hline Aard en ernst van beperklng & & & \\
\hline Problemen met zien (ref: geen problemen met zien) & & 0,10 & 0,10 \\
\hline Problemen met horen (ref: geen problemen met horen) & & - & - \\
\hline Problemen met handen (ref: geen problemen met handen) & & $-0,10$ & $-0,06$ \\
\hline Problemen met staan/lopen (ref: geen problemen met staan/lopen) & & $-0,17$ & $-0,13$ \\
\hline Ernst beperking & & $-0,09$ & $-0,11$ \\
\hline Soclaal-demograflsche kenmerken & & & \\
\hline Vrouw (ref: man) & & & $-0,20$ \\
\hline Leeftijd & & & $-0,01$ \\
\hline Opleidingsniveau midden (ref: laag) & & & - \\
\hline Opleidingsniveau hoog (ref: laag) & & & 0,17 \\
\hline $\begin{array}{l}\text { a Resultaten verkregen door middel van een logistische regressiear } \\
\text { ven }(p<0,05) \text {; niet significante effecten worden weergegeven met } \\
\text { b Model 1: variabelen over het moment van ontstaan en het verloop } \\
\text { c Model 2: model } 1 \text { met toevoeging variabelen over aard en ernst v } \\
\text { d Model 3: model } 2 \text { met toevoeging variabelen over geslacht, leeftij }\end{array}$ & $\begin{array}{l}\text { Alleen signif } \\
\text { yegevens in } \\
\text { le beperking } \\
\text { huidige bepe } \\
\text { bleidingsnive }\end{array}$ & $\begin{array}{l}\text { te effecten v } \\
\text { abel zijn regr } \\
\text { gen. }\end{array}$ & $\begin{array}{l}\text { len weergege } \\
\text { iecoëfficiënter }\end{array}$ \\
\hline
\end{tabular}


Netjes, J., Rijken, M. Ontwikkeling van lichamelijke beperking in het verleden mede bepalend voor huidige participatie op de arbeidsmarkt. Tijdschrift voor Bedrijfs- en

Figuur 1. Moment van ontstaan van beperking.

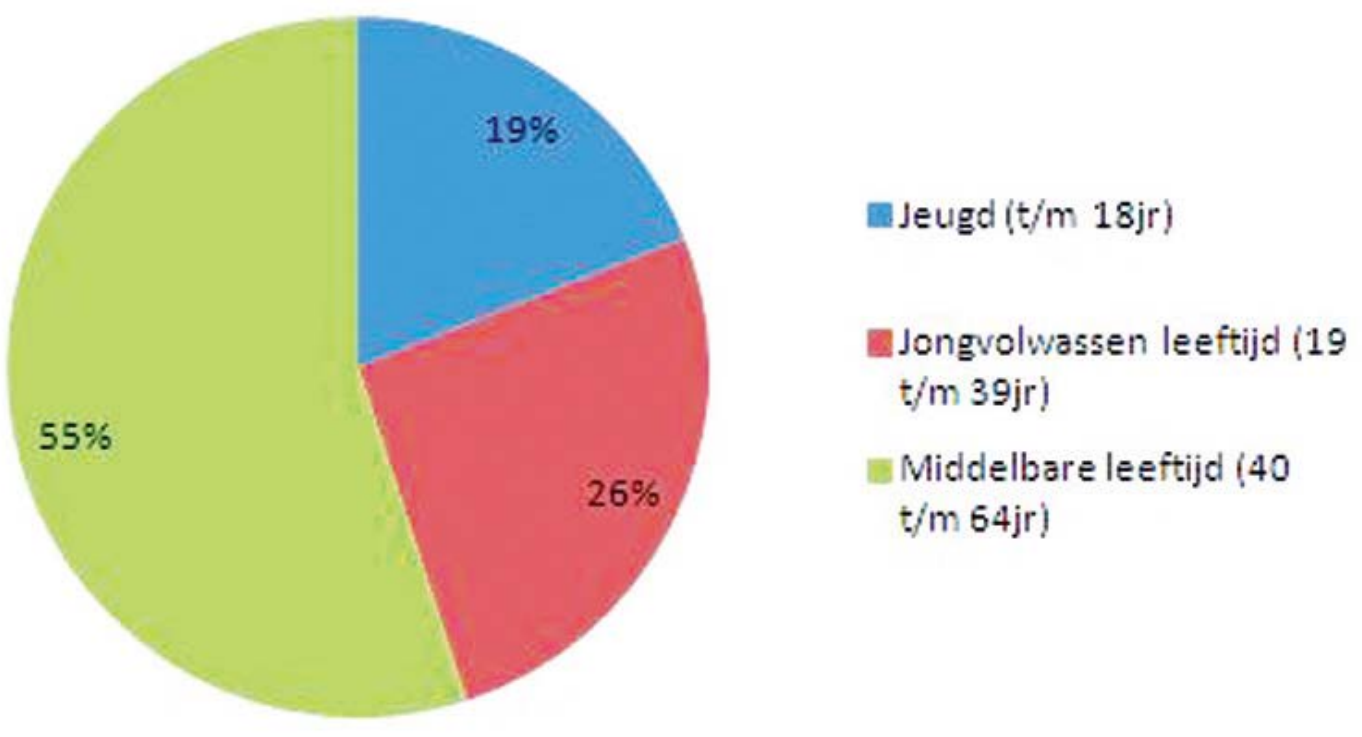

Figuur 2. Verloop van beperking.

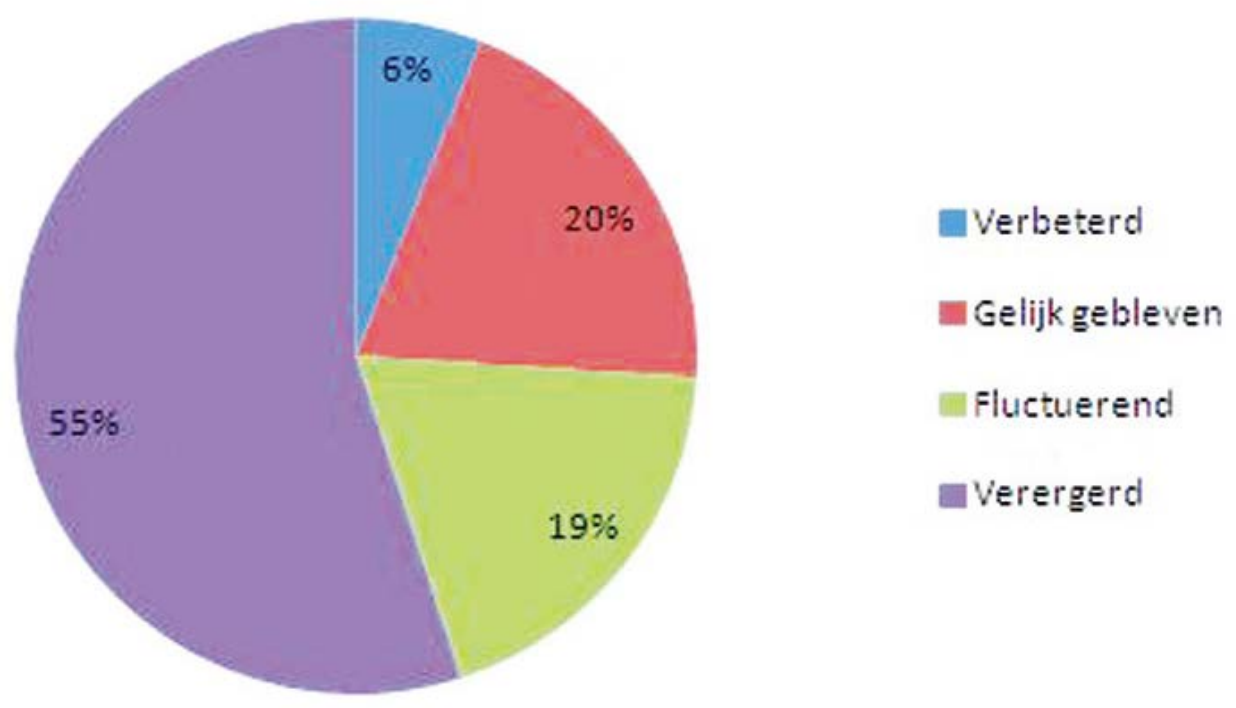


Netjes, J., Rijken, M. Ontwikkeling van lichamelijke beperking in het verleden mede bepalend voor huidige participatie op de arbeidsmarkt. Tijdschrift voor Bedrijfs- en

Figuur 3. Oorzaak van beperking.

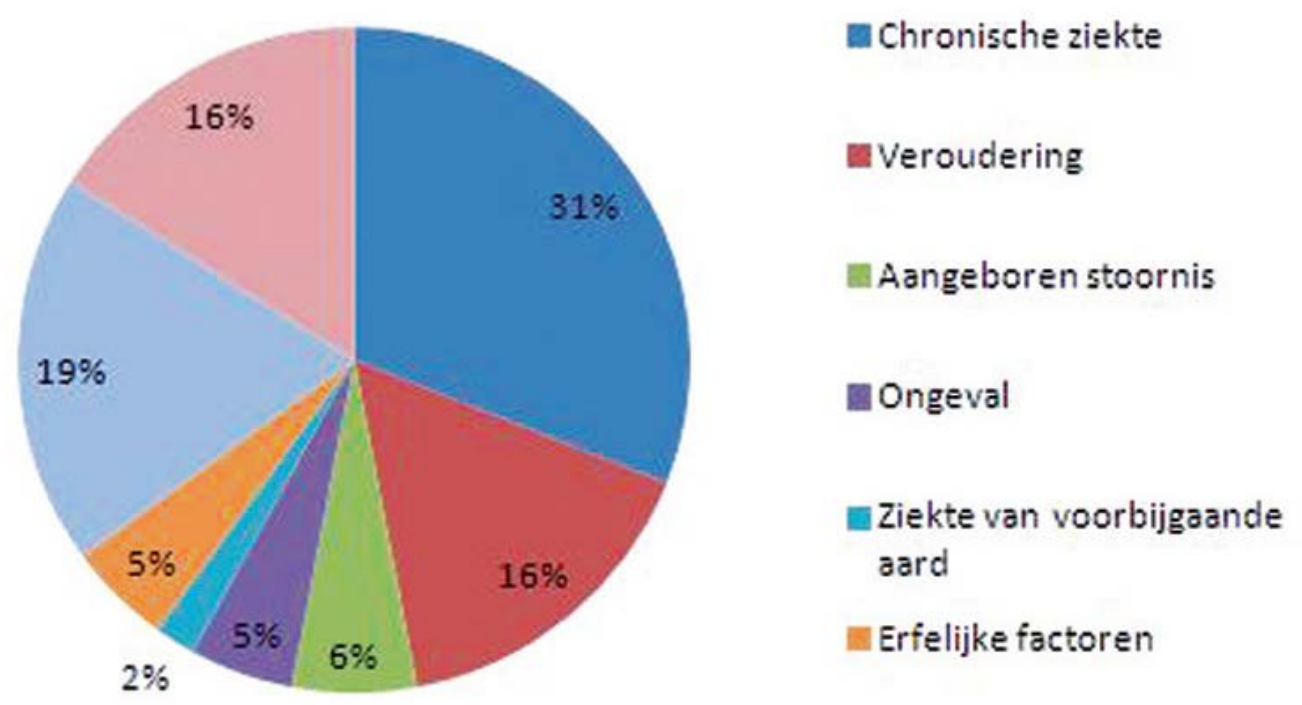

Figuur 4. Participatie op de arbeidsmarkt naar moment van ontstaan van beperking.

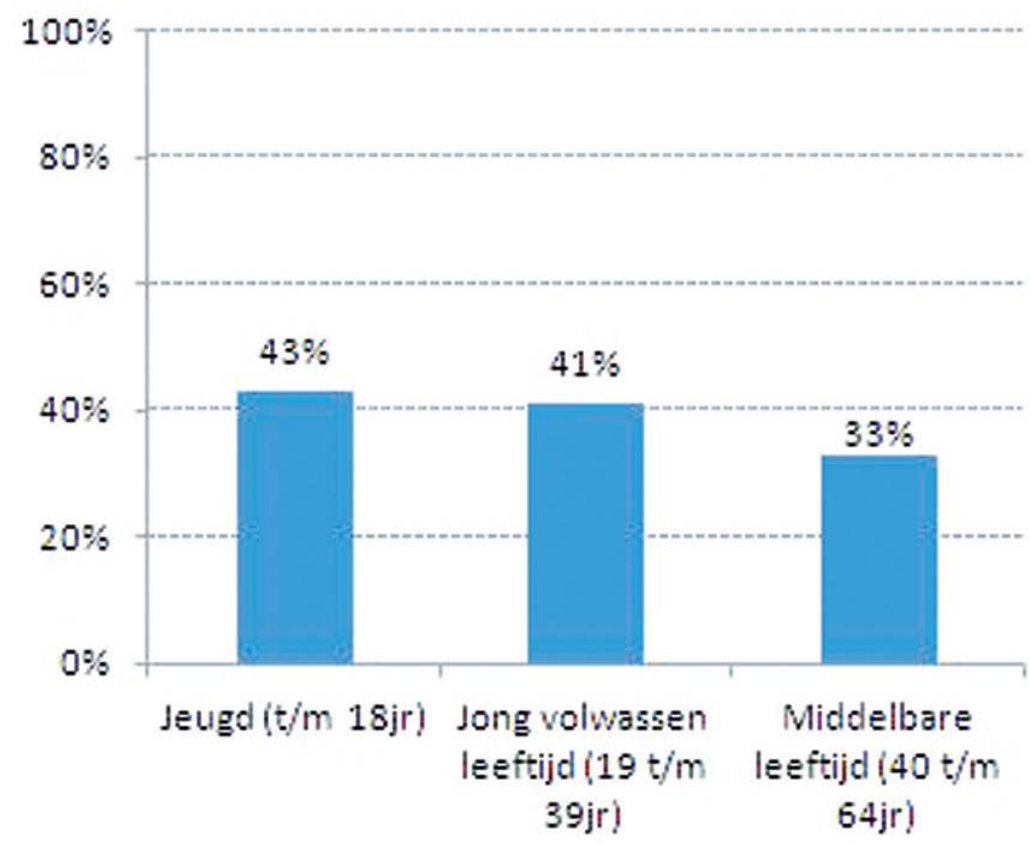

Participeertop de arbeidsmarkt 
Netjes, J., Rijken, M. Ontwikkeling van lichamelijke beperking in het verleden mede bepalend voor huidige participatie op de arbeidsmarkt. Tijdschrift voor Bedrijfs- en Verzekeringsgeneeskunde: 2012, 20(6), 248-254

Figuur 5. Participatie op de arbeidsmarkt naar verloop van beperking.

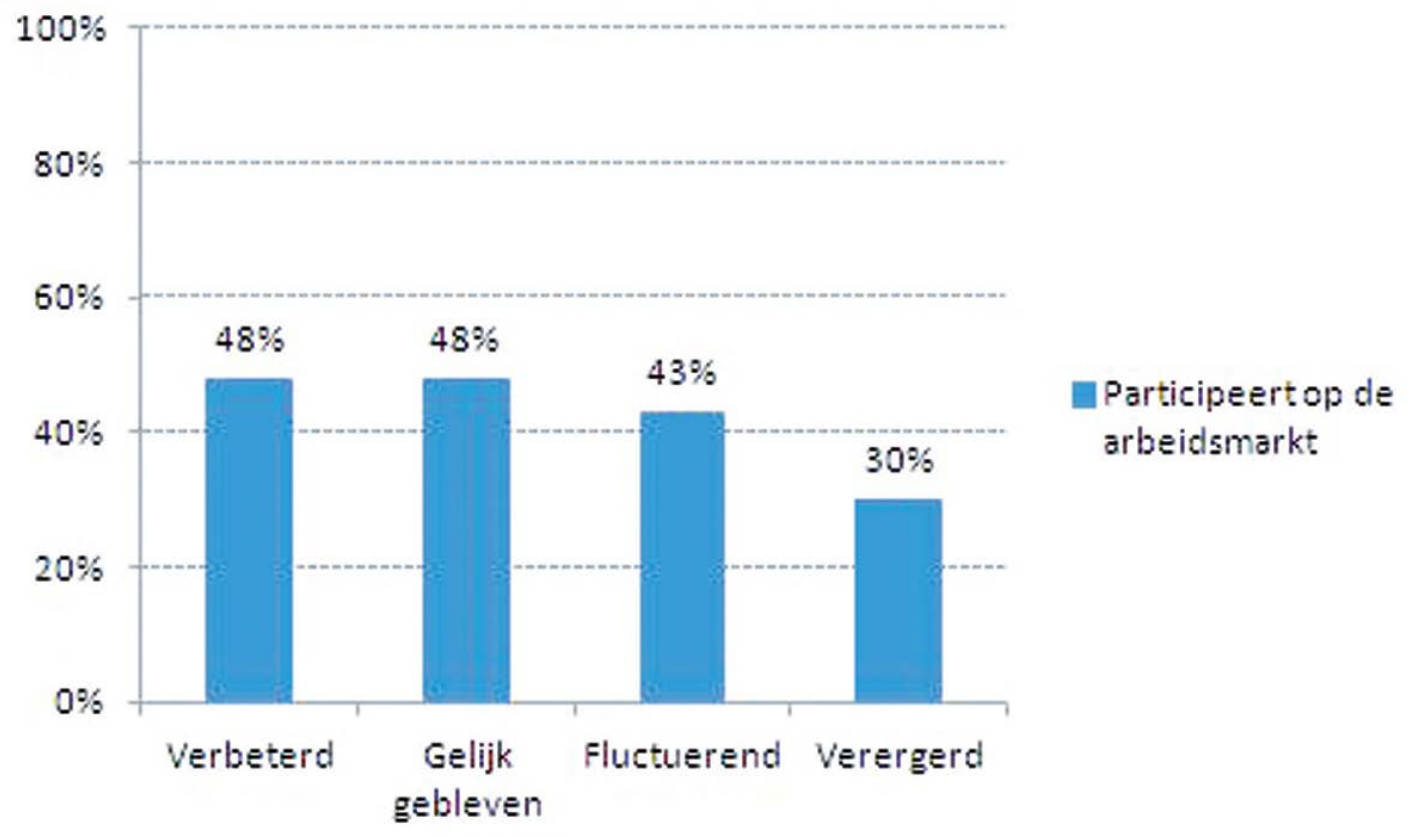

